\title{
THE ROLE OF HUMAN COAGULATION FACTORS IN SERUM- INDUCED THROMBOSIS *
}

\author{
By STANFORD WESSLER AND STANLEY M. REIMER WITH THE TECH NICAL ASSIST- \\ ANCE OF MARY-LOU BLOEDE, MARJORIE NICKLES AND BELA J. SZALAI \\ (From the Medical Research Department of the Yamins Research Laboratory, Beth Israel Hos- \\ pital, and the Department of Medicine, Harvard Medical School, Boston, Mass.)
}

(Submitted for publication July 12, 1959; accepted October 1, 1959)

With recent advances in knowledge of coagulation, the relation of specific clotting factors to the formation of intravascular thrombi and to the action of anticoagulant drugs has come under fresh scrutiny. The recognition of each new coagulation entity has, in fact, posed the problem of determining its precise role in thrombus formation as well as in blood coagulation. Since some of these factors are said to exist in precursor form in plasma and in an active form in serum $(1,2)$ and others may undergo activation after contact with foreign surfaces $(3,4)$, the possibility must also be considered that qualitative as well as quantitative alterations in these factors might be operative in patients with thromboembolic disease.

To examine the influence of specific coagulation factors on the formation of thrombi, an in vivo technic using human blood and blood products in rabbits was developed in this laboratory. It is based on the finding that the systemic infusion of serum, in contrast to plasma, rapidly induces massive thrombosis in vascular segments containing stagnant blood far removed from the site of infusion (5). The activity in serum responsible for thrombosis arises during coagulation and is not species-specific. The phenomenon of in vivo thrombosis is quantitatively related to the amount of serum infused and has formed the basis of a bioassay for measuring the serum thrombotic accelerator (STA) activity of normal human serum (6). In an effort to define the factor(s) in serum required for the induction of thrombus formation, the STA activity of normal human sera has been compared with that of sera obtained from patients with known heredofamilial coagulation defects. This report presents the results of this study.

* This study was supported by a research grant (H-1027) from the National Heart Institute, Bethesda, Md. and by a grant-in-aid from the American Heart Association.

\section{MATERIALS AND METHODS}

Sera from normal subjects and from patients with heredofamilial coagulation defects were prepared for infusion into rabbits, as previously described (6). Freshly drawn blood, transferred from glass syringes to centrifuge tubes, was allowed to clot for 2 hours at room temperature and for an additional 18 hours at $4^{\circ} \mathrm{C}$. The serum was then separated from the formed elements by centrifugation at $2,500 \mathrm{G}$ at $4^{\circ} \mathrm{C}$ for 20 minutes. We are acutely aware of the advantages of studying the behavior of coagulation factors in freshly drawn blood. However, for the purposes of standardization all sera used in this study had been frozen prior to infusion. This was necessitated by the fact that in many instances sera were obtained from patients living at a great distance from Boston. The serum samples ${ }^{1}$ used in this study were deficient in one of the following clotting factors: Factor V (ac-globulin), Factor VII (convertin), Factor VIII (antihemophilic factor), Factor IX (plasma thromboplastin component, PTC), Factor X ("Stuart" factor), Hageman factor and plasma thromboplastin antecedent (PTA).

Thrombus formation was measured in the rabbit by a standard technic (6). Briefly, human serum $(1.32 \mathrm{ml} / \mathrm{kg}$ of rabbit diluted with physiological saline to a constant volume) was infused into the marginal ear vein. Immediately following the infusion the previously freed contralateral jugular vein was gently isolated with clamps and 10 minutes later the segment was opened and examined for the presence of a thrombus. The extent of thrombosis was graded on a scale of 0 to $4:$ a score of 0 represented no thrombus formation; a score of 1 , a few macroscopic strands of fibrin; a score of 2 , several small thrombi; a score of 3,2 or more large thrombi; and a score of 4 represented a complete thrombus forming a cast of the lumen.

Thromboplastin generation was measured by the method of Biggs and Douglas (7); clotting time by the method of Lee and White (8); one-stage prothrombic activity by the method of Rosenfield and Tuft (9); pro-

1 The authors are grateful to the following investigators for serum samples used in this study: Dr. Benjamin Alexander, Boston; Dr. John Graham, Chapel Hill; Dr. Aaron M. Josephson, Chicago; Dr. Jessica Lewis, Pittsburgh; Dr. Fred Rabiner, New York; Dr. Oscar Ratnoff, Cleveland; Dr. Robert Rosenthal, New York; Dr. Herbert Sise, Boston. 
thrombin, Factor V, and Factor VII activities by the methods of Owren and Aas $(10,11)$; and Factor X activity by the method of Bachmann, Duckert and Koller (12).

In some instances, additional confirmation of the defects was obtained by cross correction experiments in the thromboplastin generation test. The probability that the STA activity in any defective serum was significantly different from that in normal serum was determined by the "exact method for small numbers" (13) and a result with $\mathrm{p}<0.05$ was called "significant." 2

\section{RESULTS}

The coagulation defects of the plasma and serum of the 20 patients used in this study were confirmed in our laboratory. The frequency of the various score thrombi resulting from the infusion of their sera is shown in Table I. The data indicate that, at a dose of $1.32 \mathrm{ml}$ of serum per $\mathrm{kg}$ of rabbit, sera obtained from patients deficient in Factor V, Factor VII, Factor VIII, and Factor $\mathrm{X}$ contain STA activity in a quantity essentially the same as that of normal serum. In striking contrast, sera from patients deficient in Hageman factor and Factor IX are essentially devoid of this activity $(p<0.05)$. Finally, sera from patients deficient in PTA exhibit a measurable but significantly smaller amount of STA activity than do normal sera.

The infusions with Factor VII-deficient sera warrant more detailed consideration. Sera from Factor VII-deficient Patient 1 were collected on 4 separate occasions : 5 infusions with the first sample failed to induce a thrombus and 1 infusion induced a score 1 thrombus; but with 3 subsequent serum samples, 10 infusions $(4,3$, and 3 infusions, respectively) each induced a score 4 thrombus. It is believed that, taken together, all the observations on Factor VII-deficient sera from Patients 1 and 2 indicate that this factor is not required for the evolution of STA activity. We have, however, no ready explanation for the failure of Factor VIIdeficient Patient 1 to evolve this activity with the first sample of serum obtained.

\section{DISCUSSION}

In vitro systems utilizing partially purified plasma or serum fractions have been helpful in unraveling some of the sequential biochemical reac-

2 We are grateful to Dr. Mindel Sheps, Assistant Professor, Department of Preventive Medicine, Harvard Medical School, for these statistical analyses.
TABLE I

STA activity of various sera

\begin{tabular}{|c|c|c|c|c|c|c|c|}
\hline \multirow{2}{*}{$\begin{array}{c}\text { Coagulation } \\
\text { defect }\end{array}$} & \multirow[b]{2}{*}{ Subject } & \multirow{2}{*}{$\begin{array}{l}\text { No. of } \\
\text { infusions }\end{array}$} & \multicolumn{5}{|c|}{ Degree of thrombosis } \\
\hline & & & $\overline{0}$ & 1 & 2 & 3 & 4 \\
\hline Normal* & 5 subjects & 24 & 1 & & & & 23 \\
\hline Factor V & $\begin{array}{l}1 \\
2 \\
3\end{array}$ & $\begin{array}{l}5 \\
5 \\
5\end{array}$ & & & & & $\begin{array}{l}5 \\
5 \\
5\end{array}$ \\
\hline Factor VII & $\begin{array}{l}1 \\
2\end{array}$ & $\begin{array}{r}16 \\
8\end{array}$ & $5 \dagger$ & 1 & & 1 & $\begin{array}{r}10 \\
7\end{array}$ \\
\hline Factor VIII & $\begin{array}{l}1 \\
2 \\
3 \\
4\end{array}$ & $\begin{array}{r}8 \\
10 \\
6 \\
2\end{array}$ & $\begin{array}{l}1 \\
1\end{array}$ & & $\begin{array}{l}1 \\
2\end{array}$ & $\begin{array}{l}1 \\
2 \\
1\end{array}$ & $\begin{array}{l}5 \\
6 \\
4 \\
2\end{array}$ \\
\hline Factor $\mathrm{X}$ & $\begin{array}{l}1 \\
2\end{array}$ & $\begin{array}{l}2 \\
2\end{array}$ & & & & & $\begin{array}{l}2 \\
2\end{array}$ \\
\hline PTA & $\begin{array}{l}1 \\
2 \\
3\end{array}$ & $\begin{array}{r}13 \\
12 \\
4\end{array}$ & $\begin{array}{l}9 \\
4 \\
2\end{array}$ & & 2 & 2 & $\begin{array}{l}4 \\
4 \\
2\end{array}$ \\
\hline Hageman & $\begin{array}{l}1 \\
2 \\
3\end{array}$ & $\begin{array}{l}3 \\
3 \\
3\end{array}$ & $\begin{array}{l}3 \\
1 \\
2\end{array}$ & $\begin{array}{l}1 \\
1\end{array}$ & 1 & & \\
\hline Factor IX & $\begin{array}{l}1 \\
2 \\
3\end{array}$ & $\begin{array}{r}10 \\
7 \\
6\end{array}$ & $\begin{array}{l}9 \\
5 \\
6\end{array}$ & 1 & $\begin{array}{l}1 \\
1\end{array}$ & & \\
\hline
\end{tabular}

* Thirty infusions (6 from each subject) of carefully collected plasma all failed to induce a clot.

†Cf. "Results" for comment.

tions that result in the elaboration of intrinsic thromboplastin and the eventual deposition of a fibrin gel. As a result of investigations of coagulation defects in patients with hemorrhagic diseases, the importance of various clotting factors in hemostasis has been substantially clarified. It remains to be demonstrated, however, whether these factors, other than thromboplastin $(5,14)$ and thrombin $(5,15)$, play a significant role, individually or collectively, in the pathogenesis of experimental intravascular thrombosis, let alone pathologic thrombosis in man.

It has been suggested, for example, that Factor VII may play a key role in initiating coagulation in vivo (16). It is well known that Factor VII will accelerate the coagulation of shed blood in vitro (17-19) and several investigators have demonstrated a temporary rise in the convertin complex during pregnancy and in the puerperium-a period when venous thrombosis and pulmonary embolism are not uncommon (20-23). However, no causal relationship has yet been demonstrated between increased levels of circulating Factor VII and the deposition of in vivo thrombi in man. An 
experimental approach to this possible relationship has been achieved in this study and valuable information obtained. Thus, the rabbit assay of human sera, prepared from blood deficient in Factor VII, has indicated that the active form of the proconvertin-convertin complex is not required for thrombus formation. These results are in accord with previous observations in this laboratory on dogs (24).

Although the identity of the STA activity of normal serum remains obscure, certain facts stand out. The data indicate that it is related, directly or indirectly, to at least three first phase coagulation factors (Factor IX, Hageman and PTA) and possibly to the complex evolved during coagulation and characterized as "intrinsic thromboplastin." Moreover, STA activity is distinct from tissue thromboplastin (5), thrombin $(5,6)$, and prothrombin $(5,6)$ as well as from Factor V, Factor VII, Factor VIII and Factor X. STA activity may have a specific and significant role in the development of intravascular thrombosis in man. Elucidation of this hypothesis must await biochemical studies directed toward its isolation, purification and characterization.

A major thesis of anticoagulant therapy has been the assumption that a predisposition to thrombosis can be effectively blocked by decreasing the blood levels of one or more coagulation factors. Here, too, there has been little direct experimental basis for assuming that reduction of any single factor depressed by the coumarin drugs, for example, is responsible for protecting a patient against thrombosis. The present study, using sera with known specific clotting defects, elucidates this point. Sera from patients deficient in Factor IX, Hageman and PTA completely or partially failed to induce in vivo thrombus formation. Of these three factors Factor IX alone is reported to be reduced by Dicumarol (25). In previous experiments in dogs it was demonstrated that marked depression of prothrombin and factor VII by Dicumarol did not block serum-induced thrombosis (24). It is possible that the antithrombotic effect of Dicumarol is related to its depression of Factor IX rather than to its effect on prothrombin, Factor VII or Factor X. Such a hypothesis is susceptible to direct experimental examination in man, using the rabbit assay of STA activity.

Previous observations in this laboratory have suggested that anticoagulant and antithrombotic effects may not be identical and that methods suitable for recognizing the one may not be adequate for characterizing the other (24). In this study the fact that the infused sera were defective in supporting thromboplastin generation, or exhibited high residual prothrombin or low Factor VII, or Factor $\mathrm{X}$ gave no clue, per se, that in vivo thrombus formation would not occur.

Finally, this investigation has provided evidence that the technic of serum-induced thrombosis offers a reproducible, physiologic method for the experimental study of thromboembolic disease and for defining the possible role of coagulation factors in the formation of intravascular thrombi.

\section{SUMMARY}

Utilizing the rabbit assay as a quantitative measure of the serum thrombotic accelerator (STA) activity of human serum, STA activity of normal human sera was compared with that of sera obtained from patients with known heredofamilial coagulation defects.

Human sera obtained from patients deficient in Factor V, Factor VII, Factor VIII or Factor X contain normal STA activity. In striking contrast, sera from patients deficient in Factor IX or Hageman factor are essentially devoid of STA activity. Finally, sera from patients deficient in plasma thromboplastin antecedent have a significantly less than normal but a measurable quantity of STA activity.

The rabbit assay of human STA activity as a useful tool in the evaluation of the efficacy of anticoagulant therapy is discussed.

\section{REFERENCES}

1. Alexander, B. Clotting factor VII (proconvertin): Synonymy, properties, clinical and clinicolaboratory aspects. New Engl. J. Med. 1959, 260, 1218.

2. Ware, A. G., and Seegers, W. H. Serum Ac-globulin: Formation from plasma Ac-globulin; role in blood coagulation; partial purification; properties; and quantitative determination. Amer. J. Physiol. 1948, 152, 567.

3. Ratnoff, O. D., and Rosenblum, J. M. Role of Hageman factor in the initiation of clotting by glass. Amer. J. Med. 1958, 25, 160.

4. Rapaport, S. I., Aas, K., and Owren, P. A. The effect of glass upon the activity of the various plasma clotting factors. J. clin. Invest. 1954, 34, 9.

5. Wessler, S. Studies in intravascular coagulation. III. The pathogenesis of serum-induced venous thrombosis. J. clin. Invest. 1955, 34, 647. 
6. Wessler, S., Reimer, S. M., and Sheps, M. C. Biologic assay of a thrombosis-inducing activity in human serum. J. appl. Physiol. 1959, 14, 943.

7. Biggs, R., and Douglas, A. S. The thromboplastin generation test. J. clin. Path. 1953, 6, 23.

8. Lee, R. I., and White, P. D. A clinical study of the coagulation time of blood. Amer. J. med. Sci. 1913, 145, 495.

9. Rosenfield, R. E., and Tuft, H. S. Estimation of prothrombin level from prothrombin time. Amer. J. clin. Path. 1947, 17, 405.

10. Owren, P. A., and Aas, K. The control of Dicumarol therapy and the quantitative determination of prothrombin and proconvertin. Scand. J. clin. Lab. Invest. 1951, 3, 201.

11. Owren, P. A. New clotting factors in Trans. Fifth Conf. Blood Clotting and Allied Problems, J. E. Flynn, Ed. New York, Josiah Macy Jr. Foundation, 1952, pp. 98-111.

12. Bachmann, F., Duckert, F., and Koller, F. The Stuart-Prower factor assay and its clinical significance. Thromb. Diath. haemor. 1958, 2, 24.

13. Fisher, R. A. Statistical Methods for Research Workers, 12th ed. London, Oliver and Boyd, 1954, pp. 96-101.

14. Spaet, T. H., and Kropatkin, M. Effect of intravenous blood thromboplastin intermediates on clotting in rats. Amer. J. Physiol. 1958, 195, 77.

15. Ungar, G. Thrombosis and stress; role of the fibrinolytic system in Thrombosis and Embolism. Proc. First Internat. Congr. Basel, Schwabe, 1955, p. 421.

16. de Nicola, P. Factor VII (SPCA) : Its physiopathologic significance. Blood 1953, 8, 947.

17. Alexander, B., de Vries, A., and Goldstein, R. A prothrombin activator in serum, and its signifi- cance in certain hemorrhagic diseases (abstract). J. clin. Invest. 1948, 27, 523.

18. Owren, P. A. The prothrombin activating complex and its clinical significance in Proc. Third Internat. Congr. Internat. Soc. Hemat., 1950. New York, Grune \& Stratton, 1951, p. 379.

19. Koller, F., Loeliger, A., and Duckert, F. Experiments on a new clotting factor (factor VII). Acta haemat. $1951,6,1$.

20. Loeliger, A., and Koller, F. Behavior of factor VII and prothrombin in late pregnancy and in the newborn. Acta haemat. 1952, 7, 157.

21. Larrieu, M. J., Soulier, J. P., and Minkowski, A. Le sang du cordon omibilical: Etude complète de sa coagulabilité, comparaison avec le sang maternel. Et. néo-natal. 1952, 1, no. 1, 39.

22. Alexander, B., Meyers, L., Goldstein, R., Gurewich, V., and Grinspoon, L. Elevated SPCA (convertin) complex in pregnancy. Its possible role in pathogenesis of thromboembolism (abstract). J. clin. Invest. 1954, 33, 914.

23. van Creveld, S., van der Paulssen, M. C. A., Versteeg, P., and Versteeg, E. T. Proconvertin content in the blood of newborn full-term and premature infants. Et. néo-natal. 1954, 3, no. 1, 53.

24. Wessler, S., Ballon, J. D., and Katz, J. H. Studies in intravascular coagulation. V. A distinction between the anticoagulant and antithrombotic effects of Dicumarol. New Engl. J. Med. 1957, 256, 1223.

25. Sise, H. S., Lavelle, S. N., Adamis, D., and Becker, R. Relation of hemorrhage and thrombosis to prothrombin during treatment with coumarin-type anticoagulants. New Engl. J. Med. 1958, 259, 266.

\section{ANNOUNCEMENT OF MEETINGS}

The Fifty-Second Annual Meeting of THE AMERICAN SOCIETY FOR CLINICAL INVESTIGATION will be held in Atlantic City, N. J., on Sunday afternoon and evening, May 1, 1960, in the Chalfonte-Haddon Hall (jointly with the AFCR); and on Monday, May 2, at 9:00 A.M., at the Casino Theater on the Steel Pier.

The Seventeenth Annual Meeting of THE AMERICAN FEDERATION FOR CLINICAL RESEARCH will be held in Atlantic City, N. J., on Sunday, May 1, 1960, at 9:00 A.M., at the Casino Theater on the Steel Pier. On Sunday afternoon and evening, May 1, 1960, a joint sectional meeting with The American Society for Clinical Investigation will be held in rooms in the Chalfonte-Haddon Hall.

THE ASSOCIATION OF AMERICAN PHYSICIANS will hold its Seventy-Third Annual Meeting in Atlantic City, N. J., at the Casino Theater on the Steel Pier on Tuesday, May 3, 1960, at 9:30 A.M., and in the Vernon Room, Chalfonte-Haddon Hall, on Wednesday, May 4, 1960, at 9:30 A.M. 